\title{
PENGARUH PEMBERIAN TUGAS BERVARIASI DISERTAI UMPAN BALIK TERHADAP MOTIVASI DAN HASIL BELAJAR MATEMATIKA
}

\author{
Slamet Riyadi \\ Universitas Tanjungpura, Pontianak \\ Email korespondensi :f2181201014@student.untan.ac.id
}

Abstrak

Penelitian pre-experimental dirancang untuk mengetahui pengaruh umpan balik terhadap motivasi belajar siswa pada materi sistem persamaan linier dua variabel. Dengan menggunakan angket motivasi belajar dan post test, pengaruh umpan balik terhadap motivasi belajar siswa pada materi sistem persamaan linier dua variabel dapat dikonfirmasi. Pemberian umpan balik dikonfirmasi dapat mempengaruhi motivasi belajar siswa dengan hasil persentase motivasi belajar siswa ratarata sebesar $70,56 \%$. Untuk memvalidasi hasil ini, kami melakukan uji hipotesis uji tanda dengan nilai terukur $Z_{h}>Z_{\text {tabel }}$ atau $-0,32>-1,645$ yang berarti Ho ditolak, dengan taraf kepercayaan sebesar $95 \%$.

Kata kunci: Umpan balik, tugas, motivasi, matematika.

\section{PENDAHULUAN}

Mutu pendidikan matematika di Kalimantan barat masih tergolong rendah. Berdasarkan data hasil ujian nasional tahun 2005/2006, Kalimantan Barat mendapatkan klasifikasi C di bidang matematika dengan rata-rata 6,21, klasifikasi A di bidang Bahasa Indonesia dengan rata-rata 7,96 dan klasifikasi $\mathrm{B}$ di bidang Bahasa Inggris dengan rata-rata 6,89, (Depdiknas Provinsi Kalimantan Barat, 2006). Salah satu faktor penyebab rendahnya mutu pendidikan matematika di Kalimantan Barat adalah lingkungan belajar yang tidak kondusif. Lingkungan belajar yang tidak kondusif menyebabkan rendahnya motivasi dan minat siswa untuk belajar.

Motivasi dalam belajar matematika berperan penting dalam meningkatkan hasil belajar siswa. Dengan motivasi yang kuat siswa akan lebih mudah dan senang belajar matematika, sehingga akan diperoleh hasil yang lebih baik. Siswa yang mempunyai motivasi tinggi dalam dirinya cenderung lebih rajin dalam mengerjakan tugas-tugas yang diberikan oleh guru dan melakukan kegiatan belajar mandiri di luar jam tatap muka.
Guru mempunyai peranan yang penting dalam meningkatkan motivasi belajar siswa. Ruseffendi (1991:8) menyatakan bahwa, "Salah satu faktor yang dapat mempengaruhi keberhasilan siswa dalam belajar adalah guru". Oleh karena itu guru haruslah selalu berusaha untuk menciptakan aktivitas siswa baik di sekolah maupun di rumah dengan jalan menempatkan diri sebagai motivator dan fasilitator dalam proses kegiatan mengajar belajar.

Pemberian tugas dalam pelajaran matematika mempunyai dampak positif. Penelitian Rif'ah (1990) menyimpulkan nilai rata-rata siswa yang diberi pekerjaan rumah lebih tinggi dibandingkan dengan nilai rata-rata siswa yang tidak mendapat pekerjaan rumah. Pemberian tugas matematika kepada siswa mendorong penguasaan konsep yang telah diajarkan di kelas lebih dipahami. Menurut Zainuzir (1979:77),'Tugas rumah yang diberikan kepada murid dapat membuat murid lebih cepat memahami pelajaran, dan merupakan suatu cara untuk mengajak murid lebih banyak belajar, sehingga kebiasaan belajar di rumah menjadi kebiasaan setiap murid".

Siswa yang termotivasi intrinsik dapat dilihat dari kegiatannya yang tekun mengerjakan tugas-tugas belajar karena merasa butuh dan ingin menguasai apa yang sedang 
dipelajari. Tetapi sedikit sekali siswa yang dorongan belajarnya merupakan motivasi intrinsik. Dari hasil penelitian Phil Louther yang diungkapkan kembali oleh Elida (1989 : 14) memberi kesimpulan, bahwa di dalam kelas banyak sekali siswa yang dorongan belajarnya adalah motivasi ekstrinsik. Untuk menumbuhkan motivasi intrinsik siswa, terlebih dahulu dapat dilakukan dengan membangun motivasi ekstrinsik. Salah satu cara yang dilakukan Phil Louther dalam membimbing siswa yang termotivasi secara ekstrinsik adalah dengan menilai tugas siswa dan memberi komentar secara tertulis terhadap tugastugas yang berbentuk tertulis (Elida, 1989 : 16). Komentar terhadap tugas-tugas dikenal dengan nama umpan balik.

Penerapan pemberian tugas bervariasi disertai umpan balik dalam pembelajaran matematika merupakan salah satu alternatif pemberian tugas. Pemberian tugas bervariasi disertai umpan balik dalam penelitian ini adalah pemberian tugas pekerjaan sekolah dan pekerjaan rumah secara bergantian dengan umpan balik berupa pemaparan nilai-nilai tugas dan komentar tertulis terhadap hasil tugas.

1. Pekerjaan sekolah dalam penelitian ini adalah tugas yang diberikan oleh guru berupa soal-soal matematika yang harus diselesaikan oleh siswa di kelas secara individu.

2. Pekerjaan rumah dalam penelitian ini adalah tugas yang diberikan oleh guru berupa soal-soal matematika yang harus diselesaikan oleh siswa di rumah secara individu

Pemberian tugas bervariasi dengan umpan balik diharapkan dapat membantu siswa dalam memahami pelajaran matematika dan membuat siswa lebih giat belajar dikarenakan adanya variasi tugas dan umpan balik yang diberikan oleh guru terhadap hasil tugas sehingga dapat meningkatkan motivasi belajar siswa di kelas X SMA Negeri 1 Sui Raya Pontianak.

\section{METODOLOGI}

Penelitian ini menggunakan bentuk praeksperimental. Rancangan yang digunakan dalam penelitian ini adalah The One Shot Case Study (Suryabrata, 2003:100) rancangan penelitian dapat pada Gambar 1.

$$
\begin{array}{|c|}
\hline \mathrm{X} \\
\hline
\end{array}
$$

Gambar 1: rancangan penelitian.

\section{Keterangan:}

$\mathrm{T}$ : Post-test

$\mathrm{X}$ : Pembelajaran matematika dengan pemberian tugas bervariasi disertai umpan balik

Rancangan percobaan memperlihatkan bahwa kegiatan dimulai dengan pembelajaran matematika yang disertai dengan pemberian tugas bervariasi disertai umpan balik. Untuk mengetahui motivasi belajar matematika siswa diberi angket motivasi belajar matematika dan untuk mengetahui hasil belajar siswa diberi tes akhir (post-test) setelah diberi pembelajaran dengan pemberian tugas bervariasi disertai umpan balik.

Dalam penelitian ini, yang menjadi populasi adalah seluruh siswa kelas X SMA Negeri 1 Sei Raya Pontianak yang terdiri dari 7 kelas tahun ajaran 2006-2007, yang sedang mempelajari Sistem Persamaan Linier Dua Variabel.

Sampel dalam penelitian ini adalah seluruh siswa kelas X-G SMAN 1 Sungai Raya sebanyak 39 siswa. Pengambilan sampel kelas dipilih secara acak, yaitu 1 kelas dari 7 kelas yang ada. Hal ini dilakukan karena penyebaran siswa pandai, sedang dan siswa yang kurang, di SMA Negeri 1 Sei Raya Pontianak merata di setiap kelas.

Pengukuran yang dimaksudkan dalam penelitian ini adalah pemberian skor angket dan pemberian skor tes akhir setelah diberikan pembelajaran matematika disertai pemberian tugas bervariasi disertai umpan balik. 
Untuk mengumpulkan data yang diperlukan dalam penelitian ini digunakan instrumen penelitian yang berupa angket motivasi belajar matematika dan tes akhir (post-test)

\section{HASIL DAN PEMBAHASAN}

Data hasil angket motivasi belajar matematika dan post-test yang diperoleh siswa kelas X G SMA Negeri 1 sungai Raya Pontianak dapat dilihat pada Tabel 1. Data yang diperoleh melalui angket pada dasarnya masih bersifat kualitatif. Untuk memudahkan dalam pengolahan data yang bersifat kualitatif perlu ditransfer dalam bentuk data kuantitatif. Adapun transfer data angket kualitatif menjadi kuantitatif dapat dilihat pada Tabel 2.

Tabel 1 : Skor motivasi belajar matematika siswa dan skor hasil post-test

\begin{tabular}{|c|l|c|c|}
\hline \multirow{2}{*}{ No } & \multicolumn{1}{|c|}{ Nama } & \multicolumn{2}{c|}{ Skor } \\
\cline { 3 - 4 } & & $\begin{array}{c}\text { Motivasi } \\
\text { siswa }\end{array}$ & Post-test \\
\hline 1 & Aditya. Saputra & 32 & 26 \\
\hline 2 & Agung. Firmnasyah & 34 & 47 \\
\hline 3 & Ani. Suryani & 43 & 48 \\
\hline 4 & Aryadi & 39 & 49 \\
\hline 5 & Dedi & 38 & 45 \\
\hline 6 & Desi Novitasari & 34 & 45 \\
\hline 7 & Diksi Mandala & 34 & 49 \\
\hline 8 & Dita Ayu L & 33 & 29 \\
\hline 9 & Dita Ana & 33 & 33 \\
\hline 10 & Dwi Astuti & 33 & 42 \\
\hline 11 & Dwi Praraningtias & 34 & 45 \\
\hline 12 & Efsi Kurniasih & 36 & 47 \\
\hline 13 & Eka fencilia & 40 & 23 \\
\hline 14 & Eko W & 30 & 27 \\
\hline 15 & Erick K & 33 & 47 \\
\hline 16 & Evi & 40 & 12 \\
\hline 17 & Febri Vestiana J & 39 & 48 \\
\hline 18 & Friska Ella P & 33 & 28 \\
\hline 19 & Guruh P & 31 & 47 \\
\hline 20 & Hamdali P & 31 & 18 \\
\hline 21 & Hardi S & 35 & 49 \\
\hline 22 & Ifana Nurul fahma & 34 & 32 \\
\hline 23 & Indra Puji Santoso & 22 \\
\hline 24 & Irawati & 29 \\
\hline 25 & Irma V & 24 \\
\hline & & 35 & \\
\hline
\end{tabular}

\begin{tabular}{|c|l|c|c|}
\hline \multirow{2}{*}{ No } & \multirow{2}{*}{ Nama } & \multicolumn{2}{c|}{ Skor } \\
\cline { 3 - 4 } & & $\begin{array}{c}\text { Motivasi } \\
\text { siswa }\end{array}$ & Post-test \\
\hline 26 & Jul Fitriandi & 33 & 34 \\
\hline 27 & Kurniawati & 31 & 41 \\
\hline 28 & Lela Nuraini & 32 & 41 \\
\hline 29 & Marlinda & 31 & 39 \\
\hline 30 & Pungki M Yadi & 39 & 42 \\
\hline 31 & Reza Arga & 41 & 30 \\
\hline 32 & Reza Kurniawan & 28 & 21 \\
\hline 33 & Riski Arisandi & 41 & 46 \\
\hline 34 & Sigid Fajar R & 33 & 26 \\
\hline 35 & Siska Danmai Yanti I & 30 & 17 \\
\hline 36 & Suci Aprianti & 42 & 11 \\
\hline 37 & Susanti & 40 & 15 \\
\hline 38 & Tyio Rizky Pratama & 31 & 15 \\
\hline 39 & Yogi Ilham Gutomo & 40 & 40 \\
\hline & Jumlah & 1376 & 1,329 \\
\hline & Rata-rata & 35,28 & 34.08 \\
\hline & SD & 3,99 & 12.02 \\
\hline
\end{tabular}

Data yang diperoleh berdasarkan jawaban siswa pada angket motivasi belajar matematika dianggap sah diolah menggunakan rumus hitung persentase, terlebih dahulu angket motivasi belajar matematika tersebut dianalisis dengan membuat tabel distribusi pilihan jawaban siswa pada angket motivasi belajar matematika, seperti terlihat pada Tabel 3.

Tabel 2: Pedoman penskoran angket motivasi.

\begin{tabular}{|c|c|c|}
\hline Pilihan & $\begin{array}{c}\text { Skor } \\
\text { Untuk } \\
\text { pertanyaan } \\
\text { positif }\end{array}$ & $\begin{array}{c}\text { Skor } \\
\text { Untuk } \\
\text { pertanyaan } \\
\text { negatif }\end{array}$ \\
\hline Sangat setuju & 5 & 1 \\
Setuju & 4 & 2 \\
Ragu-ragu & 3 & 3 \\
Tidak setuju & 2 & 4 \\
Sangat tidak setuju & 1 & 5 \\
\hline
\end{tabular}

Tabel 3: Distribusi pilihan jawaban siswa pada angket motivasi belajar matematika.

\begin{tabular}{|c|c|c|c|c|c|c|}
\hline \multirow{2}{*}{ No } & \multicolumn{5}{|c|}{ Pilihan Jawaban } & \multirow{2}{*}{ Jumlah } \\
\cline { 2 - 6 } & SS & S & R & TS & STS & \\
\hline 1 & 6 & 16 & 16 & 1 & 0 & 39 \\
\hline 2 & 6 & 14 & 9 & 7 & 3 & 39 \\
\hline 3 & 23 & 13 & 2 & 1 & 0 & 39 \\
\hline 4 & 9 & 20 & 7 & 3 & 0 & 39 \\
\hline 5 & 0 & 3 & 15 & 13 & 8 & 39 \\
\hline 6 & 7 & 8 & 5 & 16 & 3 & 39 \\
\hline 7 & 4 & 9 & 6 & 14 & 6 & 39 \\
\hline
\end{tabular}




\begin{tabular}{|c|c|c|c|c|c|c|}
8 & 6 & 23 & 7 & 2 & 1 & 39 \\
\hline 9 & 22 & 11 & 5 & 1 & 0 & 39 \\
\hline 10 & 17 & 14 & 7 & 1 & 0 & 39 \\
\hline Jumlah & 100 & 131 & 79 & 59 & 21 & 390 \\
\hline
\end{tabular}

perhitungan sebagaimana terlihat pada Tabel 5.

Tabel 5: Persentase hasil perhitungan angket motivasi belajar matematika.

Kriteria tabel di atas masih merupakan data yang bersifat kualitatif, maka perlu ditransfer dalam bentuk data kuantitatif dengan memberikan jumlah perolehan skor pada setiap item seperti tertera pada Tabel 2 dengan tujuan untuk dapat diolah dalam bentuk persentase. Setelah data ditransfer menjadi data kuantitatif, selanjutnya dilakukan perhitungan statistik dengan menggunakan rumus persentase dan rumus rata-rata (Sugiyono, 2001). Selanjutnya, untuk mengukur hasil ratarata hitung motivasi belajar matematika, juga digunakan tabel nilai konversi skor yang dikemukakan oleh Arikunto (1998) seperti terlihat pada Tabel 4.

Tabel konversi skor ini digunakan untuk memberikan tafsiran kualitatif terhadap hasil persentase. Dengan demikian berdasarkan tabel tersebut dapat dikelompokan pada rentang nilai yang mana motivasi belajar matematika siswa kelas X G SMA negeri 1 Sungai Raya Pontianak.

Tabel 4: Nilai konversi skor.

\begin{tabular}{|c|c|c|}
\hline No & Rentang Nilai & Kriteria \\
\hline 1 & $85<\mathrm{P} \leq 100$ & Sangat Tinggi \\
\hline 2 & $70<\mathrm{P} \leq 85$ & Tinggi \\
\hline 3 & $55<\mathrm{P} \leq 70$ & cukup \\
\hline 4 & $40<\mathrm{P} \leq 55$ & Rendah \\
\hline 5 & $26<\mathrm{P} \leq 40$ & Sangat Rendah \\
\hline
\end{tabular}

Untuk menjawab sub masalah yang berhubungan dengan motivasi belajar siswa ketika dalam pembelajaran matematika pada sub pokok bahasan sistem persamaan linier dua variabel diberi tugas bervariasi disertai umpan balik, dilakukan analisis data dari angket yang telah terkumpul dengan perhitungan statistik yang menggunakan rumus persentase dan rata-rata diperoleh hasil

\begin{tabular}{|c|c|c|c|}
\hline \multirow{2}{*}{$\begin{array}{c}\text { Nomor } \\
\text { Item }\end{array}$} & \multicolumn{2}{|c|}{ Skor Yang Diperoleh } & Persentase \\
\cline { 2 - 3 } & Maksimal & Responden & $(\%)$ \\
\hline 1 & 195 & 144 & 73.85 \\
\hline 2 & 195 & 130 & 66.67 \\
\hline 3 & 195 & 175 & 89.74 \\
\hline 4 & 195 & 152 & 77.95 \\
\hline 5 & 195 & 143 & 73.33 \\
\hline 6 & 195 & 117 & 60.00 \\
\hline 7 & 195 & 126 & 64.62 \\
\hline 8 & 195 & 148 & 75.90 \\
\hline 9 & 195 & 171 & 87.69 \\
\hline 10 & 195 & 70 & 35.90 \\
\hline \multicolumn{3}{|c|}{ Jumlah } & 705.64 \\
\hline
\end{tabular}

Berdasarkan Tabel 5 diperoleh hasil persentase rata-rata hitung pada semua item dengan rumus yang dikemukakan oleh Sugiyono (2001) seperti pada Persamaan 1 berikut:

$\bar{X}=\frac{\sum X}{N}$

Persentase rata-rata hitung : $\frac{705,64}{10}=70,56$ $\%$

Dengan demikian rata-rata hitung untuk menjawab sub masalah yang berkenaan dengan motivasi belajar matematika dari 39 siswa kelas X G SMA Negeri 1 Sungai Raya Pontianak diperoleh hasil perhitungan sebesar 70,56\%, berdasarkan tabel nilai konversi skor berarti berada pada rentang nilai $70-85$ dengan kriteria tinggi. Jadi motivasi belajar siswa ketika dalam pembelajaran matematika pada sub pokok bahasan sistem persamaan linier dua variabel diberi tugas bervariasi disertai umpan balik di kelas X G SMA Negeri 1 Sungai Raya Pontianak bermotivasi tinggi.

Untuk menetapkan hasil tes akhir peneliti menetapkan dua hipotesis yaitu hipotesis nol dan hipotesis alternatif. Hipotesis nol $\left(\mathrm{H}_{0}\right)$ adalah pemberian tugas bervariasi disertai umpan balik tidak dapat meningkatkan hasil belajar pada materi sistem persamaan linier dua variabel bagi siswa kelas X SMA Negeri 1 Sungai Raya Pontianak. Hipotesis alternatif 
$\left(\mathrm{H}_{\mathrm{a}}\right)$ pemberian tugas bervariasi disertai umpan balik dapat meningkatkan hasil belajar pada materi sistem persamaan linier dua variabel bagi siswa kelas $\mathrm{X}$ SMA Negeri 1 Sungai Raya Pontianak.

Dilakukan pula uji normalitas untuk mengetahui apakah data tersebut tersebar secara normal melalui langkah berikut:

1. Menentukan rata-rata dan standar deviasi:

$$
\begin{array}{ll}
\text { Rata }-\operatorname{rata}(\bar{X}) & =34,08 \\
\text { Standar deviasi }(\mathrm{SD}) & =12,02
\end{array}
$$

2. Membuat tabel frekuensi observasi dan ekspektasi:

Banyaknya data $(\mathrm{n}) \quad=39$
Rentang $(\mathrm{r}) \quad=$ Skor $_{\text {tertinggi }}-$ Skor $_{\text {terendah }}$ $=49-11=38$

Banyaknya kelas $(\mathrm{k})=1+3.3 \log 39$

Diambil k = 7

$$
=6,25
$$

Panjang kelas $(\mathrm{p})=\frac{\mathrm{r}}{\mathrm{k}}=\frac{38}{7}=5,43 \approx 6$

Diambil $\mathrm{p}=6$

3. Menentukan derajat kebebasan $(\mathrm{db})$ $\mathrm{db}=\mathrm{k}-3=7-3=4$

4. Menentukan nilai $\chi^{2}$ tabel, dari daftar tabel dengan $\alpha=0,05$

$$
\chi_{\text {tabel, }}^{2}=\chi^{2}(1-\alpha)(d b)=\chi_{(0,95)(4)}^{2}=9,49
$$

\begin{tabular}{|c|c|c|c|c|c|c|c|}
\hline $\begin{array}{l}\text { Kelas } \\
\text { Interval }\end{array}$ & $\begin{array}{l}\text { Batas } \\
\text { Kelas }\end{array}$ & $\begin{array}{l}\text { z Batas } \\
\text { Kelas }\end{array}$ & z Tabel & $\begin{array}{c}\text { Luas z } \\
\text { Tabel }\end{array}$ & $\mathrm{Ei}$ & Oi & $\frac{\left(0 i-E_{i}\right)^{2}}{E_{i}}$ \\
\hline & 8.5 & -2.13 & -0.4834 & & & & \\
\hline \multirow[t]{2}{*}{$9-14$} & & & & 0.035 & 1.365 & 2 & 0.30 \\
\hline & 14.5 & -1.63 & -0.4484 & & & & \\
\hline \multirow[t]{2}{*}{$15-20$} & & & & 0.0776 & 3.0264 & 4 & 0.31 \\
\hline & 20.5 & -1.13 & -0.3708 & & & & \\
\hline \multirow[t]{2}{*}{$21-26$} & & & & 0.1351 & 5.2689 & 6 & 0.10 \\
\hline & 26.5 & -0.63 & -0.2357 & & & & \\
\hline \multirow[t]{2}{*}{$27-32$} & & & & 0.184 & 7.176 & 6 & 0.19 \\
\hline & 32.5 & -0.13 & -0.0517 & & & & \\
\hline \multirow[t]{2}{*}{$33-38$} & & & & 0.196 & 7.644 & 2 & 4.17 \\
\hline & 38.5 & 0.37 & 0.1443 & & & & \\
\hline \multirow[t]{2}{*}{$39-44$} & & & & 0.1635 & 6.3765 & 6 & 0.02 \\
\hline & 44.5 & 0.87 & 0.3078 & & & & \\
\hline \multirow[t]{2}{*}{$45-50$} & & & & 0.1069 & 4.1691 & 13 & 18.71 \\
\hline & 50.5 & 1.37 & 0.4147 & & & & \\
\hline \multicolumn{7}{|c|}{$\chi^{2}=\frac{\left(\mathrm{o} i-E_{i}\right)^{2}}{E_{i}}$} & 23.80 \\
\hline
\end{tabular}

5. Pengujian normalitas:

Tabel 6 :Frekuensi observasi dan ekspektasi skor tes akhir.

Dari tabel frekuensi dan ekspektasi diperoleh nilai $\chi^{2}$ hitung $=23,80$ dan untuk $\chi_{\text {tabel }}^{2}=\chi_{(0,95)(4)}^{2}=9,49$. ternyata nilai $\chi^{2}$ hitung $>\chi^{2}$ tabel atau $23,80>9,49$ maka tes akhir tidak berdistribusi normal.

Hasil pengujian normalitas menunjukkan bahwa data tidak berdistribusi normal. Hal ini berarti pengujian hipotesis dilakukan dengan menggunakan statistik non parametrik. Uji yang digunakan adalah uji tanda untuk median $\eta$. Adapun langkahlangkah uji tanda sebagai berikut:

1. Menentukan hipotesis

$$
\text { - } \mathrm{H}_{\mathrm{o}}: \eta \leq 34 \mathrm{Vs} \quad \mathrm{H}_{\mathrm{a}}: \eta>34
$$

2. Pilih $\alpha=0,05$

3. Statistik uji

$$
Z_{h}=\begin{aligned}
& \frac{(\mathrm{S}-0,5)-0,5 \mathrm{n}}{0,5 \sqrt{\mathrm{n}}} \\
& Z_{h}=\frac{(19-0,5)-0,5(39)}{0,5 \sqrt{39}}
\end{aligned}
$$




$$
\begin{aligned}
& Z_{h}=\frac{18,5-19,5}{3.12} \\
& Z_{h}=\frac{-1}{3.12}=-0,32 \\
& \text { dengan } \mathrm{n}=39 \text { dan } \mathrm{S}=19
\end{aligned}
$$

4. Menentukan daerah penolakan $\mathrm{H}_{\mathrm{o}}$ $\mathrm{H}_{\mathrm{o}}$ ditolak apabila $\mathrm{Z}_{\mathrm{h}}>\mathrm{Z}_{0,05}$, atau $\mathrm{Z}_{\mathrm{h}}>$ 1,645

5. Kesimpulan

Karena $Z_{h}=-0,32$ dan daerahnya berada di sebelah kiri kurva maka $\mathrm{Z}_{0,05}$ $=-1,645$ dengan demikian $\mathrm{H}_{\mathrm{o}}$ dengan tingkat signifikan $\alpha=0,05$ ditolak. Maka dapat disimpulkan bahwa pemberian tugas bervariasi disertai umpan balik dapat meningkatkan hasil belajar pada sub pokok bahasan sistem persamaan linier dua variabel di kelas X SMA Negeri 1 Sungai Raya Pontianak.

\section{KESIMPULAN}

Pemberian tugas bervariasi Disertai Umpan Balik memberikan pengaruh yang signifikan terhadap Motivasi Belajar Matematika dan dapat meningkatkan hasil belajar siswa Kelas X SMA Negeri 1 Sei Raya Pontianak. Motivasi belajar siswa ketika dalam pembelajaran matematika pada sub pokok bahasan sistem persamaan linier dua variabel diberi tugas bervariasi disertai umpan balik tergolong tinggi dengan persentase rata-rata hitung sebesar $70,56 \%$. Pengujian hipotesis menggunakan uji tanda diperoleh $Z_{\mathrm{h}}>Z_{\text {tabel }}$ atau $-0,32>$ 1,645 yang berarti Ho ditolak. Dengan demikian, dapat disimpulkan bahwa pada taraf kepercayaan mencapai 95\%. Pemberian tugas bervariasi disertai umpan balik dapat meningkatkan hasil belajar pada materi sistem persamaan linier dua variabel bagi siswa kelas X SMA Negeri 1 Sungai Raya Pontianak.

\section{UCAPAN TERIMA KASIH}

Terima kasih penulis ucapkan kepada dosen pembimbing serta rekan-rekan mahasiswa yang telah membantu dalam penulisan artikel ini.

\section{DAFTAR PUSTAKA}

Arikunto, Suharsimi. (1998). Prosedur Penelitian. Jakarta: Rineka Cipta.

Departemen Pendidikan dan Kebudayaan, Dirjen Dikti (1994). Kurikulum Pendidikan Dasar. Jakarta : Proyek Pengembangan Pendidikan Guru Sekolah Dasar.

Elida, Prayetno. (1989). Motivasi Dalam Belajar. Jakarta: P2LPTK.

Rif'ah. (1990). Perbedaan Prestasi Belajar Bidang Studi Matematika Antara Siswa Yang Mendapat Pekerjaan Rumah Dengan Siswa Yang Tidak Diberi Pekerjaan Rumah. Skripsi. Tidak dipublikasikan. FKIP UNTAN: Pontianak.

Ruseffendi, E.T. (1991) Pengantar Kepada Membantu Guru Mengembangkan Kompetensinya Dalam Pengajaran Matematika Untuk Meningkatkan Pengajaran CBSA. Bandung: Tarsito.

Sugiyono. (2001). Statistik Non Parametris Untuk Penelitian. Alfabeta: Bandung.

Suryabrata, sumadi. (2003). Metode Penelitian. PT Raja Grafindo Persada: Jakarta.

Zainuzir. (1979). Pengaruh Tugas Rumah Terhadap Peningkatan Hasil Belajar Siswa. Padang: Indonesia 